\title{
Teachers' Recruitment as Determinant of the Academic Performance of Students' in Public Secondary Schools in Imo State
}

\author{
Dr. Israel Chijiuka Oparaji, Dr. Anthony Chudi Ugwude, Gladys Chime, and Agogbua Victor Ugochukwu \\ Department of Educational Management and Policy, Nnamdi Azikiwe University, Awka. \\ DOI: 10.29322/IJSRP.11.09.2021.p11750 \\ http://dx.doi.org/10.29322/IJSRP.11.09.2021.p11750
}

\begin{abstract}
In this study, the researcher investigated teachers' recruitment as determinant of the academic achievement of students in public secondary schools in Imo state. The descriptive survey research design was adopted for the study. Two research questions and two hypotheses guided the study. The population of the study consisted of 360 principals of public secondary schools in the study area. The sample size comprised the 360 principals that make up the population of the study because of the size of the population. A 10-item questionnaire titled, "Teachers' Recruitment as Determinant of the Academic Performance of Students' in Public Secondary Schools in Imo State Questionnaire (TRDAPSPSSIMQ)" was used to collect data from respondents. The instrument was validated by three experts, two from the Department of Educational Management and Policy and one from the Department of Education Foundations, all in the Faculty of Education, Nnamdi Azikiwe University, Awka. The instrument consisted of two sections A and B with an average correlational value of 0.84 which was considered high enough for the instrument to be reliable. The reliability of the instrument was obtained through a pilot-test and analysis by cronbach alpha. Pearson Product Moment Correlation Coefficient was used to answer the research questions and test the hypotheses at 0.05 level of significance. In testing the hypotheses, if $\mathrm{p}<$ value was greater than 0.05 , the hypothesis was accepted, when it is otherwise, it was rejected. The finding of the study among others was that most public secondary schools in the study area are understaffed and this affects the academic performance of students. It was therefore recommended that the Teaching Service Commission should recruit competent teachers and post to secondary schools in the state to enhance the academic performance of students in public secondary schools in Imo State.
\end{abstract}

Index Terms- Teachers' Recruitment, Determinant, Academic Performance, Public Secondary Schools.

\section{INTRODUCTION}

$\mathrm{T}$ The idea of teachers' recruitment at the secondary school level, whether public or private springs from the dearth of competent hands to fill vacant position of tasks in a schools. In some cases, it could arise due to the creation of new subject areas that would need extra teachers to teach such new subjects (Ezeugbor and Anozie, 2019). The identification of such job vacancies itself is the product of job analysis carried out in the school by the principal.

Recruitment can be defined as the process of advertising available job spaces in an organisation or school and selecting from the pool of applicants those considered competent in terms of certification and experience to be employed to work or teach in the school (Offor, 2018). As indicated earlier, recruitment exercise follows job analysis which helps management or education planners to determine the quality and number of teachers to be recruited based on established criteria.

Recruitment according to (Omenye, 2007) is the first step in the employment process. At the first stage, emphasis is laid on attracting a large pool of applicants in order to select from among them those who have the ability and qualifications for the jobs being advertised. The next step is the selection process. This consists of the interview process and the purpose of making a choice out of those that attended the interview on who will be engaged to work or teach in the school. At the public secondary school section, recruitment of teachers is the responsibility of the Teaching Service Commission (FGN, 2013).

Selection of teachers for engagement in a school comes after a thorough personnel planning exercise which is aimed at providing for a school, the sufficient number and quality of teachers who are ready to respond to the academic staff need of the school (Anyaogu, 2016). At this stage, the statistical data gathered during job analysis is used to generate a human resource plan for the school. As indicated earlier, this is done by the Teaching Service Commission acting on the facts and data supplied by the principals of secondary schools in the state.

As it were, personnel planning has to do with projecting the present and future human resource needs of the school, auditing the available academic staff capacity of the school and identifying teachers that need additional training to cope with the intricacies of their jobs (Ezeugbor and Anozie, 2019). Selecting teachers therefore means that such teachers are being employed. However, the concept (Selection) is not limited to employing new teachers only. It also includes promoting those fit for promotion, training those that require more training and retiring those that are due for retirement (Offor, 2010).

After the selection process, the next step is the placement of the staff recruited into the various jobs specified for them. This is the process of assigning job responsibilities to newly employed staff or teachers. At this point, the technicalities of the jobs are matched with the qualifications, experiences and competencies of 
the recruited teachers or workers (Jackson, 2012). In most cases however, orientation or induction programmes are organised for the new staff to get them acclimatised into the job environment.

A teacher is an academic staff of a secondary school. He is one trained in a particular subject area and equipped professionally to teach or impart knowledge to students. He has the teaching qualifications of B.Ed, B.A. (Ed) or B.Sc (Ed). At least the teacher possesses the NCE or even the higher qualification of M.Ed in his subject specialization. The teacher is the instrument of pedagogy in his subject and he translates the contents of the curriculum into understandable lessons for the students (Jackson, 2012). He is a master in his subject and the ethics of his job demands that he transfers what he knows in his subject area to the students. The quality of the recruitment process therefore determines to a large extent the type of teachers that are employed to bring the students into a working relationship with the contents of their chosen subjects (Igumbor, 2018).

As hinted earlier, a lot of reasons account for academic staff recruitment at the secondary school level. First is the need to get competent hands to teach the subjects that students do not have teachers to teach them, especially in the sciences. There could also be new subject areas like "marketing" carved out of "commerce", or "wood making" carved out of Introductory Technology. Such new subjects would necessarily need new teachers to teach them. The dearth of teachers in the secondary school system could also call for staff recruitment (Okara, 2014).

Whatever is the reason for academic staff recruitment, the fact remains that there is the need for recruitment process to be qualitative so that the most qualified and competent teachers could be employed to teach. The need for such quality teaches cannot be underestimated. They have the currency of their subject areas and they have the character required for their jobs (Henan, 2004).

Students' academic performance is an alternative expression of students' academic achievement or outcome. It is the result a student brings home at the end of the academic term or session. It is the representation of the students' knowledge of his subject areas and the description of his ability in his chosen subjects. It is agreed that the personal study habit of a student helps a lot on the degree of his performance but it is also factorial that the quality of teachers in a school contributes immensely to the quality of academic achievement or performance of students at the end of the school year and at the end of their secondary school training (Joke, 2017).

\section{StATEMENT OF THE PROBLEM}

Every public secondary school is expected to be equipped with human and material resources to facilitate teaching and learning. Teachers' recruitment at that level of education is therefore designed to attract and engage quality teaching personnel that will teach the students and assist the school in realizing educational set goals and objectives as contained in the National Policy of Education (FGN, 2013).

The success of students academically is enhanced by quality teachers who painstakingly prosecute the contents of their curricular and as well engage in mentoring and monitoring required to keep students on track of what they are taught in the class. Without teachers, learning will be very difficult in school and without good teachers, learning could be more difficult. This accounts for a thorough recruitment process in school.

However, the academic performance of students of public secondary schools in the study area needs much to be desired. This is why the study investigated the relationship between academic staff recruitment and the performance of student in public secondary schools in Imo state.

\section{PuRPose OF THE StUdy}

The purpose of this study is to ascertain the relationship between teachers' recruitment and the academic performance of students in public secondary schools in Imo state. Specifically, the study investigated;

1. the relationship between teachers' recruitment and students' capacity in their chosen subjects.

2. the relationship between teachers' recruitment and the academic performance of students in public secondary schools in Imo State.

\section{RESEARCH QUESTIONS}

The following research questions were adopted to guide the study;

1. What is the relationship between teachers' recruitment and students' capacity in their chosen subjects?

2. What is the relationship between teachers' recruitment and students' academic performance in public secondary schools in Imo state?

\section{HYPOTHESES}

The following hypotheses were formulated to aid the study;

1. There is no significant relationship between teachers' recruitment and students' capacity in their chosen subjects.

2. There is no significant relationship between teachers' recruitment and students' academic performance in public secondary schools in Imo State.

\section{METHOD}

The study investigated teachers' recruitment as a determinant of the academic performance of students in public secondary schools in Imo state. The design adopted in the study is a descriptive research design. Two research questions and two hypotheses guided the study. The population of the study consisted of 360 principals of the public secondary schools in the study area. There were no sampling due to the relatively small and manageable size of the population. Therefore, all the 360 principals in the public secondary schools in Imo State were used for the study. The instrument that was used to collect responses from the respondents was "Teachers' Recruitment as Determinant of the Academic Performance of Students' in Public Secondary Schools in Imo State Questionnaire, (TRDAPSPSSISQ)". The questionnaire consisted of two sections. Section A dealt with teachers' recruitment and increase in students' capacity in their chosen subjects while section B was concerned with teachers' 
recruitment and increase in the academic performance of students in public secondary schools in Imo State. The instrument is structured on a four point rating scale of Strongly Agree $(\mathrm{SA})=4$ points, Agree $(\mathrm{A})=3$ points, Disagree $(\mathrm{D})=2$ points, Strongly Disagree $(\mathrm{SD})=1$ point.

The instrument was validated by three experts, two from the Department of Educational Management and Policy and one from the Department of Educational Foundations, all in the Faculty of Education, Nnamdi Azikiwe University, Awka. The reliability of the instrument was established through a pilot-testing and analysis using Cronbach alpha, with an average correlation value of 0.84 which is considered reliable enough for the study. The researcher personally administered copies of the questionnaire to the respondents in their offices with the help of four research assistants adequately briefed on the modalities for administration and collection of the questionnaire. Out of 360 copies of questionnaire distributed, 349 copies were correctly filled and retrieved which were used for data analysis.

The Pearson Product Moment Correlation Coefficient was used to answer the research questions and test the null hypotheses 0.05 level of significance.

In testing the null hypotheses, where $\mathrm{p}$-value is less than 0.05 ( $\mathrm{p}<$ $.05)$, the null hypothesis was rejected, otherwise, the null hypothesis was accepted. Data collected were analyzed using Statistical Package for Social Science (SPSS) version 23.0.

\section{Results}

\section{Research Question 1}

What is the relationship between teachers' recruitment and students' capacity in their chosen subjects?

\section{Table 1: Pearson Correlation Co-Efficient of Teachers' recruitment and Students' Capacity in Chosen Subjects}

\begin{tabular}{lccccc} 
Variables & $\mathbf{N}$ & $\mathbf{X}$ & SD & r. & Relationship \\
\hline Teachers' recruitment (X) & & 3.36 & .69 & & \\
& 349 & & & $.78^{*}$ & Strong positive relationship \\
Students' capacity in chosen subjects (Y) & & 2.85 & .83 & & \\
\hline
\end{tabular}

Table I indicates a correlation value of $.78^{*}$ showing a strong positive relationship between the dependent and independent variables. This menas that teachers' recruitment was a strong factor in increasing students' capacity in their chosen subjects.

\section{Research Question 2}

What is the relationship between teachers' recruitment and students' academic performance in public secondary schools in Imo state?

Table 2: Pearson Correlation Co-Efficient of Teachers' Recruitment and Students' Academic Performance

\begin{tabular}{lccccc} 
Variables & N & $\mathbf{X}$ & SD & r. & Relationship \\
\hline Teachers' Recruitment (X) & & 2.81 & .79 & & \\
& 349 & & & $.81^{*} \quad$ Strong positive relationship \\
Students' Academic Performance (Y) & & 2.96 & .75 & & \\
\hline
\end{tabular}

Table 2 shows a correlation value of $.81^{*}$ showing a strong positive relationship between the dependent and independent variables. This mens that teachers' recruitment was a strong factor in enhancing students' academic performance.

\section{Null Hypothesis 1}

There is no significant relationship between teachers' recruitment and students' capacity in their chosen subjects.

Table 3: Pearson Product Moment Correlation (PPMC) Analysis of the Relationship between Teachers' Recruitment and Students' Capacity in their Chosen Subjects

\begin{tabular}{lcccccc} 
Variables & $\mathbf{N}$ & $\mathbf{X}$ & SD & rxy & P-value & Decision \\
\hline Teachers' Recruitment (X) & & 3.36 & .69 & & & \\
& 349 & & & $.78^{*}$ & .04 & Significant \\
Students' Capacity in Chosen Subkects (Y) & & 2.85 & .83 & & & \\
\hline
\end{tabular}

$* \mathbf{p}<.05 ; \mathrm{df}=349 ;$ critical $\mathbf{r}=.78^{*}$

Table 3 shows that at .05 level of significance and degree of freedom 349 , the p-value is .04 which less than the significant value $(\mathrm{p}<.05)$. Since the $\mathrm{p}$-value is less than the signficant value, the null hypothesis is rejected. This means that the relationship 
between teachers' recruitment and students' capacity in their chosen subjects is signficant.

\section{Hypothesis 2}

There is no significant relationship between teachers' recruitment and students' academic performance in public secondary schools in Imo State.

Table 4 : Pearson Product Moment Correlation (PPMC) Analysis of the Relationship between Teachers' Recruitment and Students' Academic Performance

\begin{tabular}{|c|c|c|c|c|c|c|}
\hline \multirow[b]{2}{*}{ Variables } & \multirow[b]{2}{*}{$\mathbf{N}$} & \multirow[b]{2}{*}{$\mathbf{X}$} & \multirow[b]{2}{*}{ SD } & \multicolumn{3}{|c|}{ P. } \\
\hline & & & & $\mathbf{r x y}$ & value & Decision \\
\hline \multirow[t]{2}{*}{ Teachers' Recruitment (X) } & & 2.81 & .79 & & & \\
\hline & 349 & & & $.81^{*}$ & .00 & Significant \\
\hline Students' Academic Performance (Y) & & 2.96 & .75 & & & \\
\hline
\end{tabular}

Table 4 shows that at .05 level of significance and degree of freedom 349 , the p-value is .00 which less than the significant value $(\mathrm{p}<.05)$. Since the $\mathrm{p}$-value is less than the signficant value, the null hypothesis is rejected. This means that the relationship between teachers' recruitment and students' students' academic performance in public secondary schools in Imo State is signficant.

\section{DISCUSSION}

The findings of the study in Table 1 showed that there was a strong positive relationship between teachers' recruitment and students' capacity in the chosen subjects in public secondary schools in Imo state. This presupposes a strong significant relationship between the dependent variable and the independent variables. This findings is in agreement with the submission of Offor (2010), that the students' improved strength in their chosen subjects is enhanced by the quality of teachers recruited to teach them.

Table 2 also indicated that there is a strong positive relationswhip between the dependent and independent variables. This shows that there is a significant relationship between teachers' recruitment and students' academic performance. This is supported by the works of Joke (2017) that posited that students' academic performance is improved by the work attitude of teachers recruited and posted to teach them.

Also supporting the above findings are the works of Jackson (2012) and Igumbor (2018) respectively. Each of them stated that teachers recruited and posted to schools are enhancers or boosts of students academic strength. This in other words means that there is a strong significant relationship between teachers' recruitment and students' academic achievement.

\section{CONCLUSION}

The findings of this study have revealed that there are significant relationships between the quality of teachers recruited and posted to public secondary schools and students' performance in their chosen subjects and in their examinations generally. Based on these findings, the researchers concluded that if the Ministry of Education or any other teachers' recruitment agency of government could adopt quality in terms of subject specialization as one of the criteria for teachers' could be employed and this will make for improved students' improved academic performance.

\section{RECOMMENDATIONS}

Based on the findings of the study, the researchers made the following recommendations:

1. The Ministry of Education and its teachers' recruitment agency should adopt some criteria during the recruitment of teachers in Imo State.

2. Teachers' areas of specialization should be one of the criteria for recruiting teachers in the state.

3. The Ministry of Education should also set up quality assurance mechanism to monitor teachers recruited and posted to public secondary schools as they engage in teaching and learning in their schools of primary assignment.

\section{REFERENCES}

[1] Anyaogu, (2016). Educational Management in a Digital World: Energing Perspective, Owerri; Bon Publications.

[2] Edumark, (2012). Edumark Publications Limited, Ikeja, Lagos, Nigeria.

[3] Federal Government of Nigeria, (2013). National Policy on Education; 2013. Ministry of Education; Government Press House, Abuja.

[4] Haman, J. (2004). From Personnel Administration to Human Resource Management: A Case study of State-onwad Enterprises in China (Unpublished Masters Thesis). City University of Hong Kong.

[5] Igumbor, J. (2018). Personnel Management in Education. Ibadan Varsity Press. Pp. $48-59$.

[6] Joke, M.A. (2017). Issues of Employment in the school system: An analysis of recruitment and job placement in secondary schools. Lagos University press, Yaba.

[7] Offor, N.C. (2010). Personal in Industries and Organizations. Awka Chuswat O. Partners Consults.

[8] Okara, T.J. (2017). Leadership in School Administration. University of Benin Publications; Benin city.

[9] Omenyi, A.S. (2007). Leadership and School Management: A Problem Based Approach. Awka: J. Goshen Publishers.

\section{AUTHORS}

First Author - Dr. Israel Chijiuka Oparaji, Department of Educational Management and Policy, Nnamdi Azikiwe University, Awka, ic.oparaji@unizik.edu.ng 
Second Author - Dr. Anthony Chudi Ugwude, Department of Educational Management and Policy, Nnamdi Azikiwe

University, Awka., ac.ugwude@unizik.edu.ng

Third Author - Gladys Chime, Department of Educational

Management and Policy, Nnamdi Azikiwe University, Awka,

go.chime@unizik.edu.ng

\section{Questionnaire Items}

\section{Section A}

Teachers' recruitment and increase in students' capacity in their chosen subjects

\begin{tabular}{|l|l|l|l|}
\hline S/N & Questionnaire Item & $\mathbf{X}$ & Remark \\
\hline 1 & $\begin{array}{l}\text { Teachers' recruitment is the responsibility of the Teaching Service } \\
\text { Commission. } \\
\text { It is meant to fill vacant teaching vacancies in public secondary schools. } \\
\text { It involves employing competent teachers to teach students. } \\
\text { The subject teachers recruited help to increase the capacity of students in } \\
\text { their chosen subjects. } \\
\text { This means the students' understanding of their selected subjects is increased. }\end{array}$ & 3.04 & Agreed \\
5 & \multicolumn{2}{|l}{$\begin{array}{l}\text { Strongly Agreed } \\
\text { Strongly Agreed } \\
\text { Agreed }\end{array}$} & \\
Strongly Agreed \\
\hline
\end{tabular}

\section{Section B}

Teachers' recruitment and enhanced academic performance of students in public schools in Imo state

\begin{tabular}{|c|c|c|c|}
\hline $\mathbf{S} / \mathbf{N}$ & Questionnaire Item & $\mathbf{X}$ & Remark \\
\hline 6 & Teachers' recruitment can enhance students' assimilation. & 2.86 & Agreed \\
\hline 7 & Good teachers recruited in schools make teaching and learning easy. & 2.86 & Agreed \\
\hline & They teach competently and help students interact with the contents of & & \\
\hline 8 & their curriculum. & 3.02 & Strongly Agreed \\
\hline & They are good at pedagogy. & & \\
\hline 9 & Teachers' recruitment helps to increase academic performance of & 3.04 & Strongly Agreed \\
\hline 10 & students in public secondary schools. & 3.28 & Strongly Agreed \\
\hline & & & \\
\hline & & & \\
\hline & & & \\
\hline & & & \\
\hline & & & \\
\hline & & & \\
\hline & & & \\
\hline
\end{tabular}

Fourth Author - Agogbua Victor Ugochukwu, Department of Educational Management and Policy, Nnamdi Azikiwe University, Awka. , vu.agogbua@unizik.edu.ng 